\title{
Challenges to Accessing Credit Financing from Financial Institutions by the Urban Based Street Vendors: Experience from Dar Es Salaam - Tanzania
}

\author{
Emmanuel J. Munishi ${ }^{1}$, Pauline N. Songa ${ }^{2} \&$ Mubarack, H. Kirumirah ${ }^{3}$ \\ ${ }^{1}$ Department of Business administration, College of Business Education, Tanzania \\ ${ }^{2}$ Postgraduate student, College of Business Education, Tanzania \\ 3 Department of Business Administration, College of Business Education, P.O Box 1968 Dar es Salaam, \\ Tanzania \\ Correspondence: Mubarack, H. Kirumirah, Department of Business Administration, College of Business \\ Education, P.O Box 1968 Dar es Salaam, Tanzania. E-mail: m.kirumirah@cbe.ac.tz/ babamuba@gmail.com
}

Received: October 17, 2021

Accepted: November 27, 2021

Online Published: December 14, 2021

doi:10.5539/ijbm.v17n1p65

URL: https://doi.org/10.5539/ijbm.v17n1p65

\begin{abstract}
This study assessed challenges to accessing credit financing from Financial Institutions by the urban based street vendors in Dar es Salaam - Tanzania and recommends strategies for ensuring effective access to this crucial service. The study utilised mixed methods approach design and data were collected through interview, questionnaire, Focus Group Discussion (FGD), review of secondary data, and observation techniques based on the purposive and random sample size of 104 respondents. The quantitative data were analysed descriptively by using Statistical Packages of Social Science (SPSS) while the Qualitative data were analysed content-wise by using MAXQDA software. Findings show that generally vendors were incapable of sufficiently accessing financial support from the financial institutions due to a number of reasons. These reasons include the vendors' inability to comply with the established procedures for accessing financial support, lack of financial information relating to when, how and where to acquire the financial service, vendors' inability to afford collaterals against the credit financing as well as too high loans interest rates. Another one is lack of relevant documents by the vendors required for accessing credit financing. In order to resolve the challenges, the researchers recommended equipping vendors with relevant credit financing information, prioritising provision of group loans to vendors as well as organizing the street vendors into groups. Other strategies to consider would be reduction of loan interest rates by the institutions, eliminating bureaucracy in accessing credit as well as engaging in business policy advocacy in favour of the vendors to access financial support.
\end{abstract}

Keywords: street vendors, credit financing, financial institutions, Dar es Salaam

\section{Introduction}

Informal sector is recognized globally for creation of employment and generation of income (OECD, 2017). The informal sector is broadly defined as a combination of economic activities which are carried out by the poor who are not recognized, regulated or protected by the public formal authorities (ILO, 2010). Specifically, street vending, one of the informal economic activity, involves the process of selling or offering goods and services for sale to the public without having permanent build up structures or places of doing business (Lyons Alison, 2009). Unlike the formal sector which requires large enterprises, the informal sector is free of formal management and formalisation requirements considering that traders operate with relatively small business capital and it lacks organized official institutional framework (URT, 2003; Kwaning et al., 2015).

The informal sector is an important livelihood and poverty alleviation strategy. It also serves as a springboard for the vendors towards graduating as medium and macro entrepreneurs. It has been recorded to contribute enormously to individuals' livelihoods as well as national incomes (UN-HABITAT, 2014; OECD, 2017). In Tanzania for instance, the informal sector which also includes street vending contributes to around $35 \%$ of the GDP (Mramba, et al., 2014). It has also been recorded that street vending is currently a destiny to both young men and women as well as the educated and uneducated thus being a sponge to the current unemployment crisis facing the country (Kirumirah \& Munishi, 2021; Kirumirah, 2021), thus, access to credit finance would help to 
boost their business.

Credit financing plays a very critical role in business growth and profitability. This suggests that enterprises and vendors in particular with access to credit financing from financial institutions are in a better position of maintaining stability and sustainability of their ventures. Indeed evidence shows that increase in business output, growth, sustainability are positively correlated with access to credit (Nzibonera \& Waggumbilizi, 2020; Baidoun et al., 2018). This evidence further suggests that enterprises whose owners received credit outperformed those that did not and that inadequate financing leads to other more pronounced threats to business (McGrath, 2015; ILO, 2010). Credit financing in this context involves provision of financial assistance or business capital by financial institutions that further include provision of banking services, investment services and other services relating to finance which may include providing loan facilities, currency exchange, investments and money deposits (McGrath, 2015). Financial institutions may be depository or non-depository where depository financial institutions include banks and credit unions. On the other side, non- depository financial institutions include insurance companies and mutual funds companies which do not depend on the depository of the customers (McGrath, 2015; ILO, 2010).

Despite the advantages associated with the street vending business as well as the role that credit financing plays in this particular livelihood activity, vendors are still confronted with a number of challenges related to inadequate financing (Munishi \& Casmir, 2019). Following the situation, of recent the government of Tanzania and other stakeholders have made several initiatives for ensuring the sustainability of the sector and more so their access to credit financing from the financial institutions. The enactment of the financial Act that allowed the establishment of different Micro-credit organizations, was aimed at creating avenues for credit access among street vendors and other related businesses. On the similar note, a number of financial related schemes for providing credit finance to the informal sector were established under SIDO. Moreover, of recent, the government issued Identity Cards to all street vendors across the country which were aimed at ensuring that they get all the required services including credit financing from financial institutions (Munishi \& Kirumirah, 2020). However, despite efforts undertaken by the government and its stakeholders, access to credit financing by street vendors from financial institutions has been a day-dream.

Drawing from the above background, it goes without saying that there is definitely a great challenge of accessing credit financing from the financial institutions by the urban based informal sector traders and facts reveal that reasons such a situation are inconclusive due to limited research in the area. Based on the available literature, one strand of the literature has concentrated on addressing the advantages of informal sectors to the community particularly to the people with low income (see for example, Kira, 2012; Atieno, 2011; Scott, 1999) while another addressed skill gap among the urban based street vendors Munishi \& Kirumirah, (2020), as well as general challenges of accessing business capital among the vendors (Munishi \& Casmir, 2019; Mutarubukwa, 2015). From such studies, lack of fundamental business related skills, inadequacy of capital, business space and poor support from financial institutions were among the revealed findings. While issues of stringent principles by commercial banks on accessing loan and informality status ascribed to street vendors were cited the most (Chipangura, et al., 2012; URT, 2002), such findings are inconclusive and do not reveal to what extent do they challenge vendors in accessing credit financing, hence creating a gap that needs academic attention.

This background shows that there is a need for understanding what constrains urban street vendors in accessing credit financing from financial institutions. Hence this study assesses the role of financial institutions in credit financing of informal sectors in Tanzania. Specifically it examines constraints to credit financing from the financial institutions by the street vendors and recommend strategies of enhancing the vendors' ability to access the service from financial institutions. The study further based on other studies determined the influence of identified common constraints in hampering street vendors' acquisition to credit financing. In this regard, the study tested a number of hypotheses to determine the extent to which each constraint hampers street vendors from acquiring credit financing. In this regard, researchers developed the following hypotheses;

$H_{-}(01:)$ Inadequate information on credit financial information among street vendors does not constrain street vendors from accessing credit financing from financial institutions

$H_{-}(\mathrm{O} 2:)$ Vendors' unaffordability of collateral requirement does not hinder street vendors from accessing credit financing from financial institutions

$H_{-}(\mathrm{O} 2:)$ High interest rates does not constrain street vendors from accessing credit financing from financial institutions.

$H_{-}(\mathrm{O} 4:)$ Inadequate documentation does not hinder vendors from accessing credit financing from financial institutions 
$H_{-}(05:)$ Lack of identity and physical address does not constrain vendors from accessing credit finance from financial institutions.

$H_{-}(06:)$ Lack of trust from financial institutions for loan repayment does not hinder street vendors from accessing credit finance from financial institutions

Information confirmed from these tests will suggest better and effective ways of ensuring accessibility of credit financing by the street vendors from various financial institutions. In this way the study contributes to both policy and knowledge. It informs policies regarding more practical ways of ensuring access to finance to informal sector businesses as well as informing financial institutions on effective ways of financing street vendors. It also informs the informal workers on the better ways of overcoming the current inadequate financing challenge and outlines better ways of obtaining finance from financial institutions.

\section{Area Description}

The study was carried out in Dar es Salaam, a city with five municipals which are Ilala, Temeke, Kinondoni, Kigamboni and Ubungo (DCC, 2017). The study covered the three municipals of Ilala, Temeke and Kinondoni as the major selected area with informal manufacturing entities. Dar es Salaam was deemed as appropriate study area considering that it is a major commercial centre in Tanzania and popular business destination for largest number of enterprises including informal traders. It is also, the centre for all major economic activities, hence easy to access information from targeted population (Possi \& Milinga, 2018).

\section{Methods and Technique}

\subsection{Research Approach and Design}

The mixed methods research approach was used in this study. The approach suggests that both qualitative and quantitative data be collected either, sequentially or concurrently and analysed jointly or separately leading to meaningful interpretations and findings. In this study, data were collected concurrently. Mixed methods approach is useful in that qualitative do complement on the weaknesses of each specific method (Creswell et al., 2011). Because the study intended to give a clear picture of the phenomenon, it was useful for researchers to employ the explanatory design because of its ability in explaining phenomena generating and developing knowledge and understanding (Adam \& Kamuzora, 2008).

\subsection{Sampling and Sampling Technique}

The study drew from a sample size of 140 respondents including, 95 street vendors and 45 officers from financial institutions as well as business development related organisations responsible for ensuring credit financing to enterprises. Researchers' targeted different subsectors of urban street vendors including fashion and electronics vendors, food and beverage vendors as well as fruits and vegetables vendors. Both street vendors and key informants from the relevant organisations were sampled purposively based on their knowledge, experience and positions they held with regards to the topic under the study. These key informants were obtained from the Small Industry Development Organization (SIDO), Tanzania Investment Centre (TIC), and Tanzania Trade Development Authority (Tan Trade), Tanzania private sector foundation (TPSF), Financial Institutions (FIs) and Local Governments (LGs).

\subsection{Data Collection Techniques}

Data collection for this study was undertaken using questionnaire, interview and documentary review. In the first place the questionnaire was administered to the urban informal street vendors. This questionnaire included five points Likert scale questions that intended to solicit quantitative data on the extent to which each factor impeded street vendors from accessing credit financing from the financial institutions. Interviews were carried to selected key informants from different organizations and they were intended to explore and examine and explain the ways in which particular factors constrained vendors from accessing credit financing from the financial institutions. Secondary data were obtained from local newspapers, recently published research papers and magazines.

\subsection{Data Analysis}

Each set of data was treated separately. To both datasets, cleaning, summarizing and coding were done. Data with quantitative nature were subjected to SPSS and descriptive statistics were used to make meaning out of the analyzed data. From descriptive analyses, hypotheses were tested to find out the extent to which each impediment hinders street vendors from obtaining credit finance from financial institutions. Qualitative data, on the other hand was handled using MAXQDA 10 software to generate meaningful expressions. In this regard, descriptive statistics obtained were explained and cemented by quotes obtained from interviews and 
documentary reviews. Throughout the study, all ethical standard was adhered.

\section{Findings and Discussion}

This study found out that, various factors hindered the vendors from accessing finance from Financial Institutions which include lack of enough financial information, collateral requirements, high loan interest rates, inadequate documentation, lack of particular place of doing business, lack of trust from financial institutions. In the following section we discuss the extent to which each factor impeded the access to this important service among the vendors.

4.1 Descriptive statistics on Challenges to accessing Credit Financing by the Urban Based Street Vendors

Table 1. Descriptive statistics

\begin{tabular}{lllll}
\hline Challenges & N & Minimum & Maximum & Mean \\
\hline $\begin{array}{l}\text { Inadequate information on credit financing among } \\
\text { street vendors }\end{array}$ & 140 & 1.00 & 5.00 & 3.93 \\
Unaffordability of collateral requirements & 140 & & & \\
High interest rates on loans & 140 & 1.00 & 5.00 & 3.80 \\
Inadequate documentation & 140 & 1.00 & 5.00 & 3.64 \\
Lack of identity and physical address & 140 & 1.00 & 5.00 & 3.83 \\
Lack of trust by financial institutions for loan & 140 & 1.00 & 5.00 & 3.91 \\
repayment & & 1.00 & 5.00 & 3.76 \\
\hline
\end{tabular}

Findings in Table 1 indicated that, inadequate information on credit financing among street vendors scored the highest with a mean score of 3.93 and standard deviation of 1.030. This indicates that the factor was among constraints hindering street vendors from accessing credit finance. Moreover, Lack of trust by financial institutions for loan repayment also scored highly meaning that it was among the serious challenges. Further findings indicate lack of identity and physical address (mean score 3.91) was also ranked among the serious challenges to credit financing. It was also revealed that high interest rates (mean score 3.64), unaffordability of collateral security (mean score 3.80) and inadequate documentation (mean score 3.83) were among the serious challenges observed to hinder street vendors from accessing credit finance from financial institutions in the country. Such results imply that all cited challenges were in one way or the other associated to constraining street vendors from accessing credit finance in one way or the other. Findings on individual challenges are presented in the subsequent sections.

\subsection{Inadequate Information on Credit Financing among Street Vendors}

The first aspect of the first objective was to examine how the inadequate Credit Financial Information among the Street Vendors impeded access to the credit financing from the financial institutions. According results revealed that $1.6 \%$ strongly disagree; $6.6 \%$ disagree; $21.3 \%$ neither disagree nor agree; $41 \%$ agree; and the remained $29.5 \%$ strongly agree as further shown the figure that follows. This implies that there is inadequate credit financing information among street vendors. Indeed, these findings were also supported by a number of interview responses as one of the respondents puts it here under:

Definitely, we don't have adequate information on how to access loans and other financial support from our banks and even microfinance organisations. These people (workers from banks) don't talk to us. May be because they know that we don't have big business capitals. The other day my friend went there and he was referred to the website. The other one was provide with a leaflet in a foreign language. So who would be able to understand such complicated information among us? Mind you we are just Street Vendors (Male, Urban Street Vendor, (25), Ilala Municipal Council) 


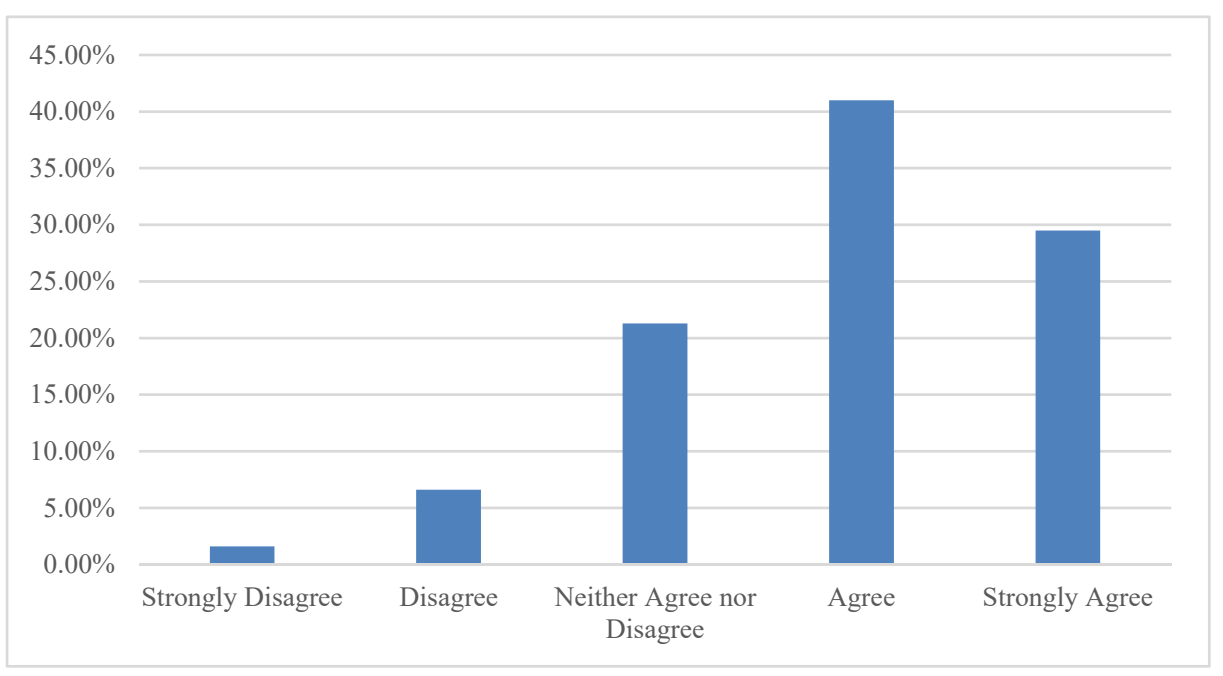

Figure 1. Response on Inadequacy of Credit Financial Information

\subsection{Unaffordability of Collateral Requirements}

The second aspect of the second objective assessed the extent to which Unaffordability of Collateral Requirements e.g. assets like land title deeds and other properties by street vendor in accessing financial credit from financial institutions. The findings revealed that $10.7 \%$ strongly disagree, $3.9 \%$ disagree, $25.2 \%$ neither agree nor disagree while $28.2 \%$ agree and $32 \%$ strongly agree that collateral requirement is a challenge to street vendors as elaborated under the Table below. These findings paint a picture that, to a great extent Unaffordability of Collateral Requirements impedes vendors from accessing the credit financing from the commercial institutions. These findings were also supported by some interview respondents as represented by one of them hereunder.

Usually they [financial institutions] require some collaterals. However, this does not work on our side because, one the one hand we lack some of these movable and non-movable assets. However, sometimes it becomes even more complicated when some of our assets such as land are not registered or formalised. For example, one of our friends was denied a loan simply because he did not have a title deed for his piece of land. So how do we move ahead? (Female, Urban Food Street Vendor, (22), Temeke Municipal Council).

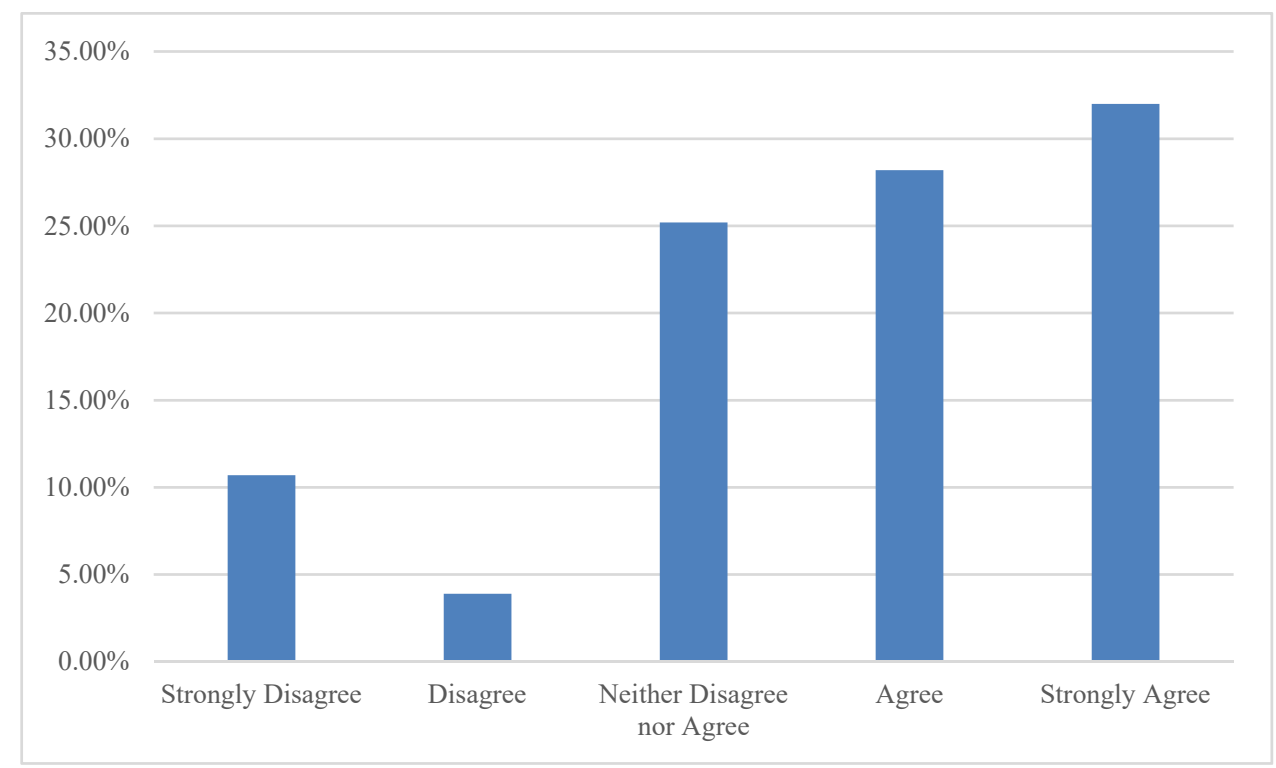

Figure 2. Responses on unaffordable collateral requirement 


\subsection{High Interest Rates on Loans}

Moreover, the third aspect this paper looked into the extent to which High Loans Interest Rates impeded access to financial support from financial institutions, by the vendors. The findings for this particular analysis revealed that only 5\% strongly disagree, $8.8 \%$ disagree, $13.7 \%$ neither agree nor disagree while $43.1 \%$ agree and the remained $29.4 \%$ strongly agree that the interest rate is high for street vendors to afford. This generally suggests that High Loans Interest Rates impedes access to the credit financing from the financial institutions.

These findings also supported by the interview responses as typified by one of the respondents below:

We are basically afraid of going for those loans because interest rate can accumulate to the extent that it equalises with the principle amount you borrow. My friend got a loan and I think he was subjected to unfair rates. Within just two years the amount doubled. Now as you know, when it doubles you fail to pay and they come to confiscate your property. Now everything ends from there. It pains, but that is the truth. (Male, Urban Street Vendor, (24), Kinondoni Municipal Council).

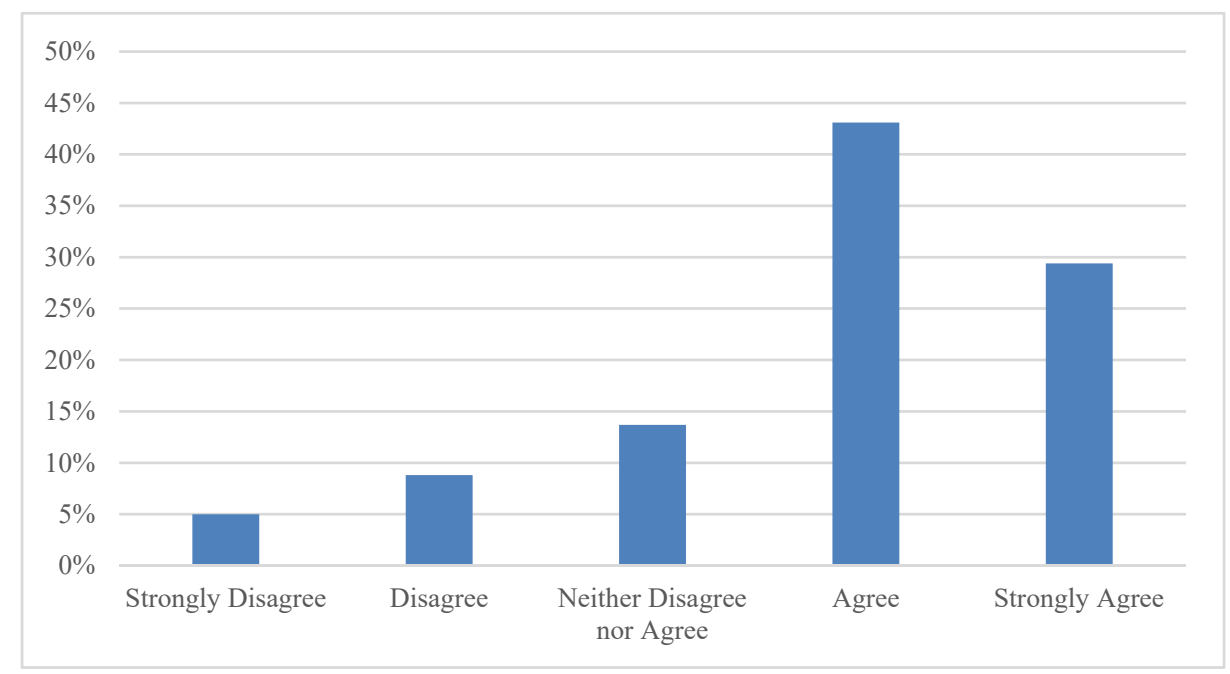

Figure 3. Response on high interest rate of credits from financial institutions

\subsection{Inadequate Documentation}

The fourth aspect of this paper assessed the extent to which Inadequate Documentations impeded the vendors from successfully accessing the financial assistant from financial institutions. The findings for this analysis revealed that $1.6 \%$ strongly disagree; $8.2 \%$ disagree; $11.5 \%$ neither agree nor disagree; $26.2 \%$ agree; and the remained $52.5 \%$ strongly agree that documentation is a challenge to street vendors to access credit from financial institutions. These findings are also supported by the interview responses as mentioned by one of the respondents below:

It is true that financial Institutions particularly banks require several documents from potential financial customers, such as valid identity documents, bank statements, proof of income, proof of residence and a minimal balance prior to the opening of accounts. But the truth is that most of the street vendors do not have these documentations owing to their social economic status. For example if I opened the Bank account I will have no money to save there. After role I keep money in my mobile phone. (Male, Urban Street Vendor, (19), Ilala Municipal Council). 


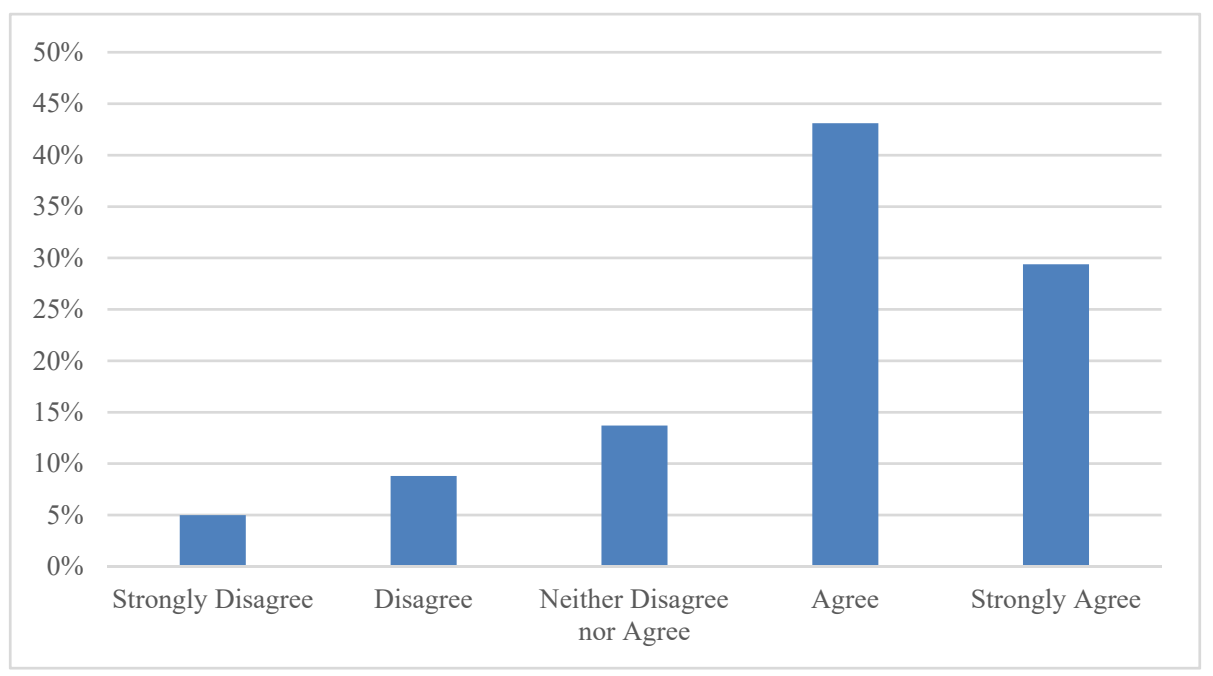

Figure 4. Inadequate Documentations

\subsection{Lack of Identity and Physical Address}

The fifth aspect of this paper examined the manner in which Lack of Identity and physical address impeded access to the financial support from the financial institutions by the street vendors. According findings for this assessment revealed that, 34\% strongly disagree that the street venders have special premises located for doing business, while $2.9 \%$ disagree and $32 \%$ neither disagree nor agree; $15.5 \%$ agree; and $15.5 \%$ strongly agrees. This obviously reveal that lack of identity and physical addresses severely impeded the vendors from accessing this service. These findings are supported by the interview responses as below.

Definitely these vendors lack specific places for doing business because their capitals are small and they do not afford to pay for the offices and make other tax compliances of running business. The absence of particular place of business limits the trustworthy from the financial institutions due to fear of finding street vendor for repayment of loans (Male Key informant (45), Kinondoni Municipal Council).

Another key informant adds here under:

Informal traders in many urban areas work in illegal places, land or buildings where they engage in unauthorized business at times. Due to the limited financial abilities to most of workers in informal sectors end up utilising locally available scrap construction materials which are of low costs. They lack access to mortgage and other subsides finance because they mostly do not have necessary requirement of obtaining loan facility (Female Key informant (34), Ilala Municipal Council).

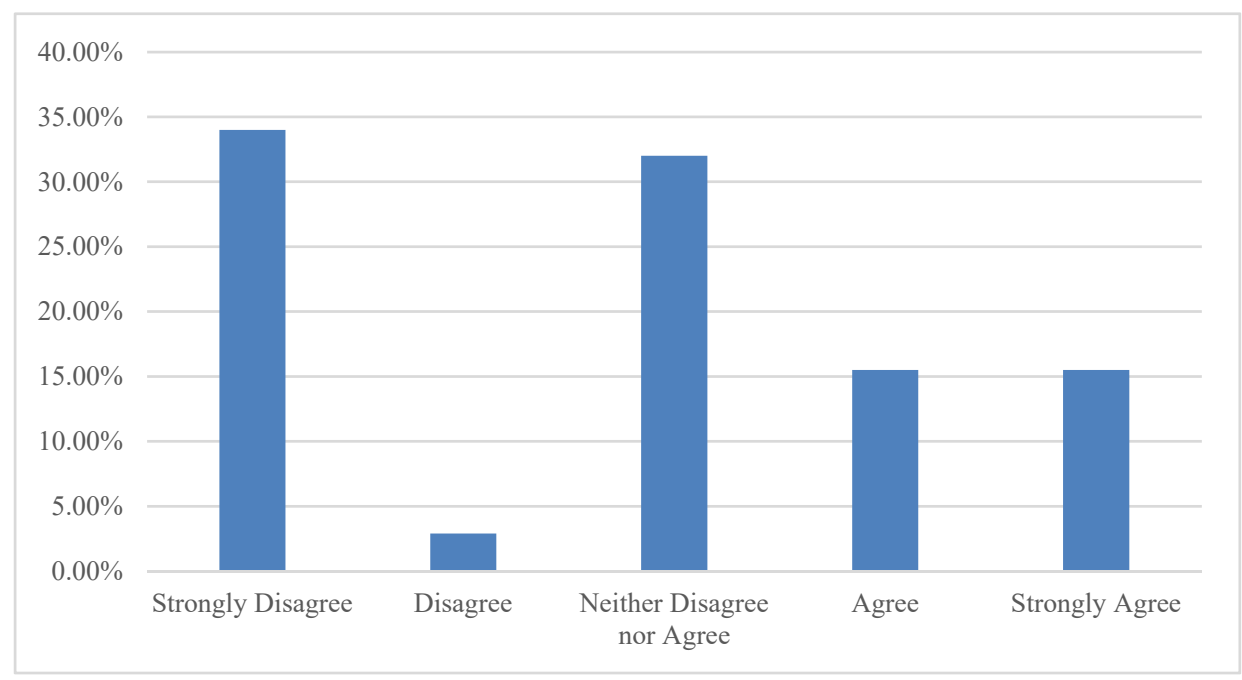

Figure 5. Lack of identity and physical addresses 


\subsection{Lack of Trust by Financial Institutions for Loan Repayment}

The $6^{\text {th }}$ aspect of this paper was to examine how lack of trust from financial Institutions for Loan Repayment impeded the vendors from accessing the services from financial institutions. The findings for this analysis noted that $5.5 \%$ strongly disagree, $3.6 \%$ disagree, $14.3 \%$ neither disagree nor agree while $23.3 \%$ agree and $43.3 \%$ strongly agree. These findings suggest that lack of trust from Financial Institutions significantly impeded the vendors from accessing this important service from the financial institutions. These responses were also echoed during the interview sessions as testified by one of the respondents here under:

This is true beyond doubt. Several times we have witnessed that street vendors are denied the loans simply because they have low capital which suggests that they will not be able to repay the loans. This therefore becomes difficult for the financial institutions to provide loans to them because of fearing non-repayment of loans. So would say that lack of trust is a challenge to accessing credit finance from financial institutions. (Female Key informant (35), Temeke Municipal Council).

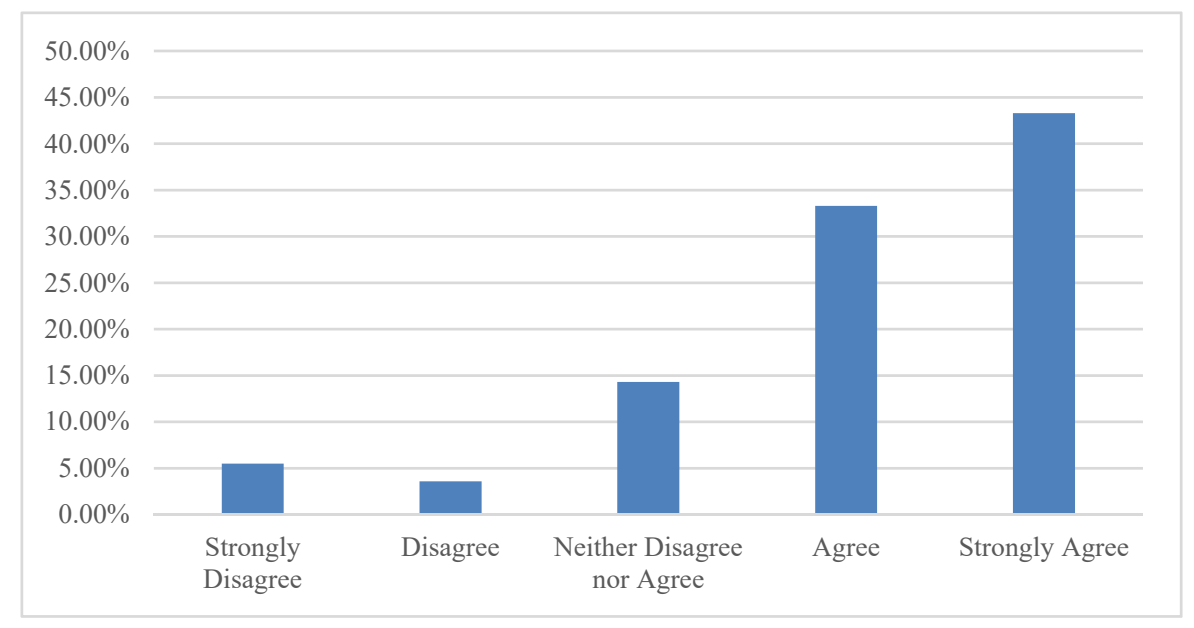

Figure 6. Extent to which lack of finance reduce trust towards street vendors

\subsection{Hypotheses Testing}

In order to confirm findings obtained in the descriptive analysis of this study, and determine the extent to which cited challenges inhibit vendors from accessing credit finance, researchers decided to test hypothesis. In the course of testing the hypotheses earlier developed by the researcher. The researcher with a number of null hypotheses hypothesized that inadequate financial information on credit financing, unaffordability of collateral security, high interest rate, inadequate documentation, lack of identity and physical address and lack of trust from financial institution for loan repayment do not constrain street vendors from accessing credit financing. All six challenges depicted that they all were cited and statistically proved to be great challenges that inhibit vendors from accessing credit finance from financial institutions. Based on the findings collected, researchers were compelled to reject all the six null hypothesis and opt for the alternative hypothesis as all challenges were statistically significant to hindering access to credit finance at significance level of 0.05 throughout all tested variables. Hence, it can be stated that, inadequate financial information on credit financing, unaffordability of collateral security, high interest rate, inadequate documentation, lack of identity and physical address and lack of trust from financial institution for loan repayment constrain vendors from accessing credit finance from financial institutions as depicted in Table 2 and 3. 
Table 2. Regression analysis on challenges of accessing credit finance

\begin{tabular}{|c|c|c|c|c|c|}
\hline & \multicolumn{2}{|c|}{ Unstandardized coefficients } & \multicolumn{3}{|c|}{ Standardized coefficients } \\
\hline & $\mathrm{B}$ & Std error. & Beta & $\mathrm{T}$ & Sig \\
\hline Constant & 2.345 & 0.461 & & 5.084 & \\
\hline $\begin{array}{l}\text { Inadequate information on credit financing among } \\
\text { street vendors }\end{array}$ & 0.088 & 0.143 & -0.061 & 0.652 & 0.002 \\
\hline Unaffordability of collateral requirements & 0.059 & 0.07 & -0.062 & 0.739 & 0.001 \\
\hline High interest rates on loans & 0.134 & 0.071 & 0.174 & 1.787 & 0.000 \\
\hline Inadequate documentation & 0.196 & 0.82 & 0.226 & 2.059 & 0.02 \\
\hline Lack of identity and physical address & 0.077 & 0.06 & 0.097 & 1.102 & 0.043 \\
\hline $\begin{array}{l}\text { Lack of trust by financial institutions for loan } \\
\text { repayment }\end{array}$ & 1.34 & 0.0780 & 0.146 & 1.762 & 0.001 \\
\hline
\end{tabular}

Table 3. Summary of Results of measured variables

\begin{tabular}{lll}
\hline Variable & Results & Remarks \\
\hline $\begin{array}{l}\text { Inadequate information on credit financing } \\
\text { among street vendors }\end{array}$ & At 0.05 & Statistically significant \\
$\begin{array}{l}\text { Unaffordability of collateral requirements } \\
\text { High interest rates on loans }\end{array}$ & At 0.05 & Statistically significant \\
$\begin{array}{l}\text { Inadequate documentation } \\
\text { Lack of identity and physical address }\end{array}$ & At 0.05 & Statistically significant \\
$\begin{array}{l}\text { Lack of trust by financial institutions for } \\
\text { loan repayment }\end{array}$ & At 0.05 & Statistically significant \\
\hline
\end{tabular}

\subsection{Discussion of Findings}

The findings reveal also that there are some constraints facing street vendors in accessing credit finance from financial institutions. These constraints include lack of enough financial information among the street vendors; failure of small street vendors to afford collaterals where majority of respondents contended that street vendors fails to obtain credit finance from financial institutions because they are not capable of producing land title deeds and other properties required. This finding reflects the findings by Abu-Hadi, (2013) who pointed out the challenges facing small businesses in accessing financial institutions to include lack of collateral because majority of street vendors are from poor families who does not own valuable properties for securing their loans; low repayment capacity because street vendors are engaging into small business which commonly targets on affording their day to day livelihood rather than generating long term profit; and lack of guarantor since majority of street vendors are not trusted due to nature of their business.

This is also reflected by (Kira, 2012; Munishi \& Kirumirah, 2020), who contended that financial institutions require high valuable collaterals, higher interest rates, high insurance cover for the facilities and financial statements which in return becomes difficult for the informal sectors to afford. Moreover, Satta $(2003 ; 2006)$ amplify this argument by point out lack of adequate and reliable collateral, lack of appropriate instrument to manage risk, not being familiar with complicated information about informal business and perceived risk make banks in Tanzania become unwilling to provide the much-needed finance to small informal business which includes street vendors.

Moreover, high loan interest rates were also found as a challenge to access loans. Majority of respondents opined that the interest rate is very high and majority of street vendors cannot afford it. Street vendors' fails or are not willing to obtain loans because they are fearing the existing high loan interest rates when considering their poor nature of business. This finding reflects the literature by Abdul, (2011) with the research Impacts of Microfinance Institutions on the growth of Micro and Small Enterprises and Owners in Tanzania where found a number of things which includes the problem of interest rates, information, and MFIs facing scarcity of resources which makes the credit finance not accessible by majority of informal sectors including street vendors.

This is reflected in the study by (Mramba, 2015; Msoka, 2007) (Munishi \& Kirumirah, 2020) who stated that majority of Street Vendors are low-income earners who are informally employed carry out most of their day today dealings in cash, since they do not qualify to utilize formal banking institutions for the purposes of saving and/or budgeting for future financial obligations. They are largely remained excluded from accessing and 
utilizing most basic financial services and financial products.

\section{Conclusion and Recommendations}

\subsection{Conclusion}

In conclusion, this study has assessed the role of financial institutions in credit financing of urban street vendors, to specifically examine constraints to accessing credit financing from financial institutions by the vendors and recommend strategies for ensuring effective access to this crucial service. Findings show that generally vendors were incapable of sufficiently accessing financial support from the financial institutions due to a number of reasons. These reasons include the vendors' inability to comply with the established procedures for accessing the financial support, lack of financial information relating to when and how to acquire the financial service, vendors' inability to afford collaterals against the credit financing as well as too high loans interest rates. Another one is lack of relevant documents by the vendors required for accessing credit financing. In order to resolve the challenges, the researchers recommend equipping vendors with relevant credit financing information, prioritising provision of group loans to vendors as well as organizing the street vendors into groups. Other strategies to consider would be reduction of loans interest rates by the institutions, eliminating bureaucracy in accessing credit as well as engaging for business policy advocacy in favour of the vendors to access financial support. Accordingly, this paper contributes to both policy and knowledge aspects of financing of the street vendors. Recommendations for these study are further enumerated below in much greater details.

\subsection{Recommendations}

As can be recalled this research has specifically examined constraints to accessing credit financing from financial institutions by the urban informal vendors and recommend strategies for ensuring effective access to this crucial service by the vendors. In this section therefore we present strategies for ensuring access to credit financing by the street vendors based on the above presented findings summary and conclusion.

- Firstly vendors should be equipped with relevant information related to credit financing since it was found that, lack of such information was a hindrance to accessing credit financing from financial institutions by the vendors. Such information should be provided by financial institutions as well as organizations responsible for providing business development services and advocacy to business people and enterprises. This can be further realized through use of advertisements, seminars, workshops and training on the available opportunities related to continent access to credit financing from financial institutions.

- Another strategy would be prioritising provision of group loans to vendors [group financing arrangements]. These recommendations are useful considering the fact that, most of the vendors do not have collaterals and other Bank and financial related documentations to qualify them access financial services from the financial institutions. Again this is an initiative to be undertaken by all financial institution and the existing business development services organisations.

- Another strategy closely related to the above strategy, would be the initiative to organize street vendors into effective groups that would qualify and enable them obtain credit financing from financial institutions. This is because they miss collaterals and other credentials for borrowing funds from financial institutions. This is the task to be undertaken by financial institutions, relevant business development and advocacy organisations as well as well as the local government authorities.

- Another strategy is reduction of loans interest rates by the financial institutions to allow and attract more street vendors' access credit financing from financial institutions. This can also include provision of loans without interests so as to attract street vendors who are not willing to obtain loan due to fear of imposed interests.

- Moreover, review of credit financing procedures and mechanism should be undertaken by both the government in collaboration with the financial institutions. This would help avoid bureaucracy in accessing credit financing by the street vendors.

- Another strategy is review of the criteria of obtaining credit from financial institutions to allow majority of street vendors to obtain credit. This would involve removing all criteria not in favour of street vendors such as identification, physical address, and documentations which are difficult to be obtained by street vendors.

- Another strategy is business policy advocacy; meaning that various stakeholders such as business development organisations as well as financial organisations should join hands together and advocate against all impediments that hinder the vendors from successfully accessing the credit financing form the financial institutions.

\section{References}

Aabii, M. (2014). The Pecking Order Theory and SME s Financing: Insight into the Mediterranean Area and a Study in the Moroccan Context Myers. Journal of Small Business and Enterprise Development, 14(4), 
27-43.

Adam, J., \& Kamuzora, F. (2008). Research methods for business and social studies. Mzumbe book project, Mzumbe.

Aghion, J., \& Bolton, M. (2012). Finance for All: Policies and Pitfalls in Expanding Access. Washington, DC: The World Bank.

Amanda, R. (2012). Small and Micro enterprises access to external finance. London, UK: Department for business innovation and skills.

Andoh, F. K., \& Nunoo, J. (2011). Sustaining Small and Medium Enterprises through Financial Service Utilization: Does Financial Literacy Matter? Retrieved from http://ageconsearch.umn.edu/bitstream/123418/2/Sustaining\%20sme\%20article.pdf\%20jacob\%20nunoo1.p df

Atieno, R. (2009). Linkages, Access to Finance and the Performance of Small Scale Enterprises in Kenya. Retrieved

from http://erepository.uonbi.ac.ke/bitstream/handle/11295/27196/Atieno_Linkages,\%20access\%20to\%20finance $\% 20$ and $\% 20$ the $\% 20$ performance $\% 20$ of.pdf? sequence $=2$

Atieno, R. (2011). Formal and Informal Institutions' Lending Policies and Access to Credit by Small-scale Enterprises in Kenya: An Empirical Assessment. Nairobi, KE: AERC Research Paper III. Research Consortium.

Ayyagari, M., Asli, D., \& Vojislav, M. (2012). Firm Innovation in Emerging Markets: The Role of Finance, Governance, and Competition. Journal of Financial and Quantitative Analysis, 46, 1545-80. https://doi.org/10.1017/S0022109011000378

Baidoun, S. D., Lussier, R. N., Burbar, M., \& Awashra, S. (2018). Prediction model of business success or failure for Palestinian small enterprises in the West Bank. Journal of Entrepreneurship in Emerging Economies. https://doi.org/10.1108/JEEE-02-2017-0013

Cassar, G., \& Holmes, S. (2013). Capital Structure and Financing of SMEs: Australian Evidence. Accounting and Finance, 43, 123-147. https://doi.org/10.1111/1467-629X.t01-1-00085

Central Bank of Kenya. (2012). Bank Supervision Annual Report 2012. Nairobi, KE: Central Bank of Kenya.

Charbonneau, J., \& Menon, H. (2013). A Strategic Approach to SME Exports Growth. The section of Enterprise Competitiveness - ITC. Taipei, TWN: Secretariat, Confederation of Asia-Pacific Chambers of Commerce and Industry.

Cheluget, D. C. (2013). Effects of Access to Financial Credit on the Growth of Women Owned Small Retail Enterprises in Uasin Gishu County: A Case of Kapseret Constituency. (Unpublished Master's Thesis), University of Nairobi.

Chipangura, A., \& Kaseke, N. (2012). Growth constraints of small and medium enterprises (SMEs) at Glenview Furniture Complex (GFC) in Harare (Zimbabwe). International Journals of Marketing and Technology, 2(6), 40-83. $\quad$ Retrieved from https://www.indianjournals.com/ijor.aspx?target $=$ ijor:ijmt\&volume $=2 \&$ issue $=6 \&$ article $=004$

Cox, J. W., \& Hassard, J. (2010). Triangulation in Organizational Research Representation of Organizational Science. Management Science, 12, 109-133. https://doi.org/10.1177/1350508405048579

Creswell, J. W., Klassen, A. C., Plano Clark, V. L., \& Smith, K. C. (2011). Best practices for mixed methods research in the health sciences. Bethesda (Maryland): National Institutes of Health, 541-545.

Esperanca, J. P., Gama, A. P. M., \& Gulamhussen, M. A. (2013). Corporate Debt Policy of Small Firms: An Empirical (Re) Examination. Journal of Small Business and Enterprise Development, 10, 62-80. https://doi.org/10.1108/14626000310461213

Gangata, J., \& Matavire, U. (2013). Economic Implications of Lending of Microfinance Institutions on Micro-and Small- Scale Enterprises. (Unpublished Master's Thesis), University of Nairobi.

Gatari, K. (2012). Determinants of Financing Obstacles among Small and Medium Enterprises in Kenya. (Unpublished Master's Thesis), University of Nairobi.

Gitman, L. J. (2003). The Principles of Managerial Finance (7th Ed.). New York, NY: Pearson Education Inc.

Hilgert, A., Hogarth, M., \& Beverly, G. (2013). Household Financial Management: The Connection between 
Knowledge and Behavior. Federal Reserve Bullet in July, 309-322.

ILO. (2010). Managing Risk and Designing Products for Micro Finance - Features of an Emerging Model. Washington, DC: CGAP Occasional Paper 11.

Johnson, S. (2014). The impact of microfinance institutions in local financial markets: a case study from Kenya. Journal of International Development, 16(3), 501-517. https://doi.org/10.1002/jid.1088

Kakuru, H. (2013). Financing Small and Medium Scale Enterprises (SMEs): Uganda's experience. Bank of Uganda working paper, $\mathrm{WP} / 03 / 01$.

Kauffmann, C. (2010). Financing SMEs in Africa. Policy insight No.7, EOCD Development Centre.

Kessy, S., \& F. Urio, (2006). The contribution of microfinance institutions to poverty reduction in Tanzania. Dar es Salaam. Mkuki na Nyota Publisher.

Kira, A. R. (2012). The impact of firm Characteristics in Access of Financing by Small and Medium-sized Enterprises in Tanzania. International Journal of Business and Management, 7(24), 108-113. https://doi.org/10.5539/ijbm.v7n24p108

Kirumirah, M. H. (2020, August). Equality and Access to Urban Public Open Spaces by the Poor Urban Street Vendors in Dar Es Salaam. In Applied Research Conference in Africa (pp. 183-193). Springer, Cham.

Kirumirah, M., \& Munishi, E. J. (2021). Characterizing street vendors in the urban settings of Tanzania: Towards sustainable solutions to vendors' challenges. In Mojekwu, J. N., Thwala, W., Aigbavboa, C., Atepor, L., Sackey, S. (Eds.), Sustainable Education and Development. ((1st ed., pp. 245-261). Switzerland AG: Springer International Publishing. Retrieved from https://www.springerprofessional.de/en/characterizing-street-vendors-in-the-urban-settings-of-tanzania-/190 76766

Kuzilwa, J. A. (2005). The Role of Credit for Small Business Success: A Study of the National Entrepreneurship Development Fund in Tanzania. Journal of Entrepreneurship, 14(1), 131-161. https://doi.org/10.1177/097135570501400204

Kuzilwa, J. A., \& Mushi, K. (2014). Credit needs for Small Business in Tanzania. Banker's Journal, 3(1), 1-8.

Kwaning, C. O., Nyantakyi, K., \& Kyereh, B. (2015). The Challenges behind SMEs' Access to Debts Financing in the Ghanaian Financial Market. International Journal of Small Business and Entrepreneurship Research, $3(2), 16-30$.

Lydiah, Z. (2012). Finance for All? Policies and Pitfalls in Expanding Access. Washington, DC: The World Bank.

Mbonyane, B., \& Ladzani W. (2011) Factors that Hinder the Growth of Small Businesses in South African townships. European Business Review, 23(6), 550-560. https://doi.org/10.1108/09555341111175390

McGrath, P. (2015). Informal financial assistance for patients with a hematological malignancy: implications for oncology social work practice. Social Work in Health Care, 54(10), 892-908. https://doi.org/10.1080/00981389.2015.1061088

Mramba, N., Sutinen, E., Haule, M., \& Msami, P. (2014). Survey of mobile phone usage patterns among street vendors in Dar es Salaam city- Tanzania. International Journal of Information Technology and Business Management, 28(1). http://dspace.cbe.ac.tz:8080/xmlui/handle/123456789/282

Msoka, C. T. (2007). Street vending in Dar es Salaam, Tanzania: The dynamics behind continuing vulnerability, Prepared for the Living on the Margins Conference. Stellenbosch March, 26-28/ 2007. Stellenbosch S.A.

Munishi, E. J., \& Casmir, R. (2019). Paper Title: Overcoming Business Capital Inadequacy and Resilience Implications for the Urban Street Vendors' Operations in Morogoro Municipality, Tanzania. Business Education Journal (BEJ), 2(2), 15.

Munishi, E. J., \& Kirumirah, M. (2020). Skills gap among the Urban Street vendors in Tanzania: Cases of Dar es Salaam and Morogoro Urban settings. Business Education Journal (BEJ), 2(1). Retrieved from https://bej.cbe.ac.tz/index.php/bej/article/view/218

Munishi, E. J., \& Kirumirah, M. (2020). Vendors' licensing and permit issuing in urban setting: Constraints \& Implications for vending operations in Dar es Salaam -Tanzania. Business Education Journal (BEJ), 2(1).

Mutarubukwa, P. (2015). The role of entrepreneurship in combating youth unemployment and social crime in Tanzania. 
Mwangi, J., \& Bwisa, H. (2013). Challenges Facing Entrepreneurs in Accessing Credit: A Case of Youth Entrepreneurs in Makuyu, Kenya. Prime Journal of Business Administration and Management (BAM), $3(10), 2251-1261$.

Nzibonera, E., \& Waggumbulizi, I. (2020). Loans and growth of small-scale enterprises in Uganda: A case study of Kampala Central business area. African Journal of Business Management, 14(5), 159-169. https://doi.org/10.5897/AJBM2020.8985

OECD. (2017). Financing SMEs and Entrepreneurs 2017: An OECD Scoreboard. Paris, FR: OECD Publishing.

Possi, M. K., \& Milinga, J. R. (2018). Learner diversity in inclusive classrooms: The interplay of language of instruction, gender and disability. MOJES: Malaysian Online Journal of Educational Sciences, 5(3), 28-45.

Raphael, L., \& Jogsoon, S. (2012). What Role Can Financial Policies Play in Revitalizing SMEs in Japan? IMF working Paper.

Satta, T. A. (2003). Enterprise characteristics and constraints in developing countries evidence from a sample of Tanzania micro and small-scale enterprises. International Journal of Entrepreneurship and Innovation, 4(3), 112-120. https://doi.org/10.5367/000000003101299546

United Republic of Tanzania. (2009). Small and Medium Enterprises Policy. Dar es Salaam, Tanzania.

URT. (2009). Development policy Small and Medium Policy, Dar es Salaam, Tanzania.

Vera, D., \& Onji, K. (2010). Changes in the Banking System and Small Business Lending. Small Business Economics, 34(3), 293-308.

Zeller, P. (2014). The Determinant of Household Access and Participation in Formal and Informal Credit Market. The Institute of International Food Policy Research, 7(2), 23-31.

\section{Copyrights}

Copyright for this article is retained by the author(s), with first publication rights granted to the journal.

This is an open-access article distributed under the terms and conditions of the Creative Commons Attribution license (http://creativecommons.org/licenses/by/4.0/). 